\title{
Metabolic Syndrome and Incidence of Stroke
}

\author{
Qing Qiao ${ }^{1,2, *}$, Regzedmaa Nyamdorj ${ }^{1,2}$ and Lei Zhang ${ }^{1,2}$ \\ ${ }^{1}$ Department of Public Health, University of Helsinki PL41, Mannerheimintie 172, 00014 Helsinki, Finland and \\ ${ }^{2}$ National Institute for Health and Welfare, Helsinki, Finland
}

\begin{abstract}
The relationship between metabolic syndrome and stroke has not been investigated as widely as that for coronary heart disease. The aim of the study is to make an overall review of the published articles on metabolic syndrome and the stroke incidence. Eight population-based prospective studies are included and a meta-analysis based on the published data was performed. The combined overall hazard ratio for stroke incidence was similar (around 1.7) for different definitions of the metabolic syndrome. A European study which has compared four different definitions using paired homogeneity test did not find any difference in the prediction of the ischemic stroke incidence and there was also no differences between a full definition and its single individual components.
\end{abstract}

\section{INTRODUCTION}

Since 1998 many different definitions for the metabolic syndrome have been introduced. The World Health Organization (WHO) was the first to introduce a provisional definition for the metabolic syndrome in 1998 [1] and this was revised in the 1999 [2]. The WHO includes in its definition the insulin resistance under hyperinsulinemic and euglycemic conditions, and microalbuminuria [2]. The European Group for Study of Insulin Resistance (EGIR) introduced a simple definition based on the WHO one in 1999, in which the insulin resistance was defined using the top quartile distribution of fasting insulin concentration among the nondiabetic individuals of the background population and waist circumference was used to replace the body mass index (BMI) and waist to hip ratio (WHR) [3]. In 2001, the National Cholesterol Education Program Adult Treatment Expert Panel III (NCEP_2001) approved a new definition based on five components and any three abnormalities of the five forms a definition [4, 5]. Insulin resistance was not included in the NCEP definition. The NCEP_2001 definition was further modified in 2004 (NCEP_2004) [6], in which the fasting plasma glucose (FPG) cut-off value was lowered from 6.1 $\mathrm{mmol} / \mathrm{l}$ to $5.6 \mathrm{mmol} / \mathrm{l}$. The American Association of Clinical Endocrinologists (AACE) made a clinical definition in 2003 $[7,8]$. The latest major definition came from the International Diabetes Federation (IDF). The IDF consensus group approved their definition in 2005 to emphasize the importance of central obesity $[9,10]$. The major components of these definitions are more or less similar but with different emphasis (Table 1).

The prevalence of the metabolic syndrome varies depending on the definitions used even in the same study population $[11,12]$. A great surge of publications has been created to compare the differences of these definitions with

*Address correspondence to this author at the Department of Public Health, University of Helsinki PL41, Mannerheimintie 172, 00014 Helsinki, Finland; Tel: +358 504151578; Fax: +358 9 19127313;

E-mails: qing.qiao@ktl.fi; qing.qiao@helsinki.fi regard to their prevalence and their prediction of cardiovascular disease (CVD) and diabetes. Based on the published data, several meta-analyses were carried out and published. These data have unequivocally shown that the metabolic syndrome of different definitions all increased the risk of CVD [12-15] and diabetes [16, 17], but the prediction was stronger for diabetes than for CVD. A few studies have, however, challenged the definition of the metabolic syndrome by showing that the individual metabolic component predicted the CVD by a similar magnitude as that of the full definition of the syndrome [18-20], and fasting glucose alone was a stronger risk predictor for the future diabetes than was the full definition of the metabolic syndrome. In this article relationship between metabolic syndrome of different definitions and the incidence of stroke was quantitatively reviewed.

\section{DATA SOURCES AND LIMITATIONS}

Publications in English language from 1975 onwards on metabolic syndrome and stroke were searched from PubMed using title terms "metabolic syndrome" and "stroke". Prospective studies with population-based cohort design that have estimated the hazard ratio of the metabolic syndrome for predicting stroke were eligible for the current review, and summarized in Table 2. Eight studies were included which consisted of limited ethnic groups: American white\&black in two studies (one in middle-aged and another in elderly population)[21, 22], Finnish in two (one in middle-aged men and another in elderly men and women)[23, 24], Japanese in two (middle-aged) $[25,26]$, and Chinese in one study (middleaged)[27]. A meta-analysis based on individual data of Finnish and Swedish populations was also included [28]. Multivariate adjusted hazard ratios were reported in the Table 2 if more than two hazard ratios have been presented in one article. As shown in the Table 2 the adjustment varies among studies. Three of the eight studies have estimated the ischemic stroke, four with all stroke and one did not mention the type of the stroke. Different definitions of the metabolic syndrome have been applied and indicated in the Table $\mathbf{2}$. 
Table 1. Major Definition of the Metabolic Syndrome of Different Organizations

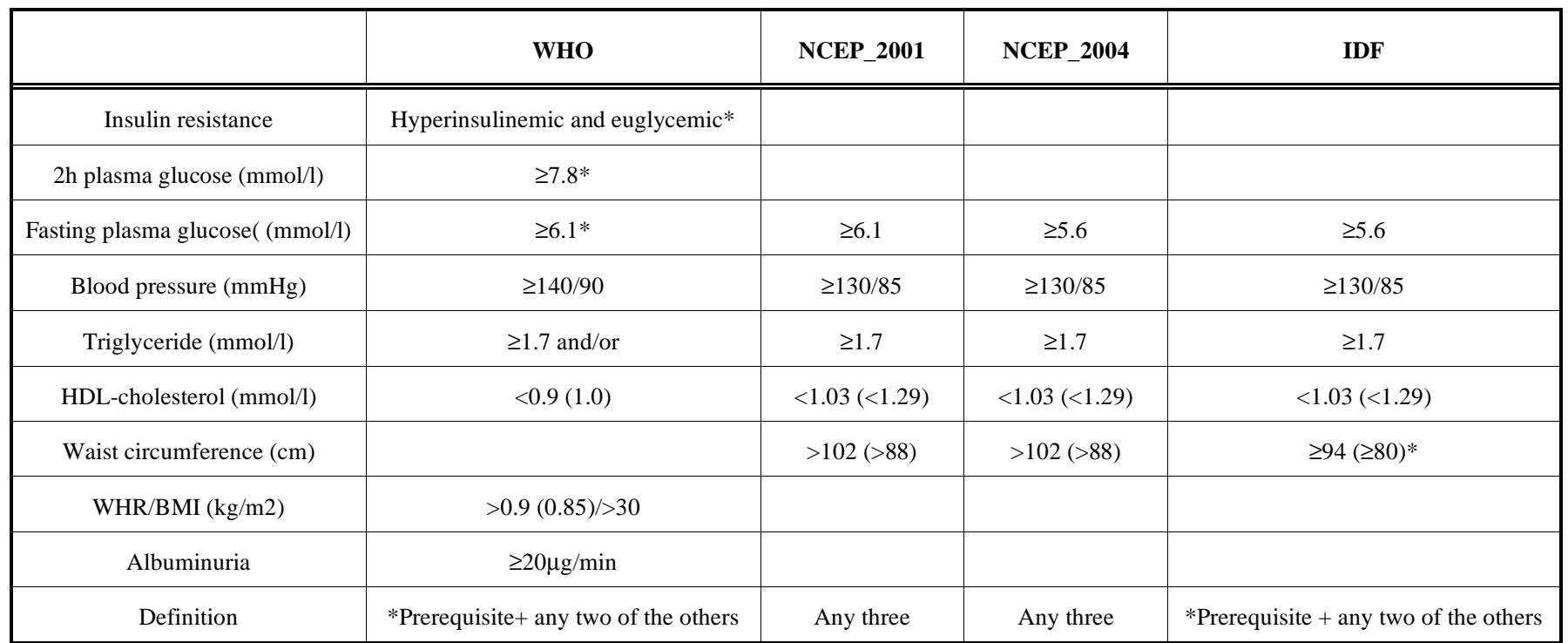

Previously diagnosed diabetes or those taking anti-hypertensive treatment are counted in all four definitions.

*Prerequisite.

\section{DATA ANALYSIS}

Multivariate adjusted hazard ratios $(95 \% \mathrm{CI})$ for stroke attributed to metabolic syndrome of different definitions was collected from each study, and combined into an overall hazard ratio by a fixed-effects approach according to the method detailed by Fleiss [29], the combined overall hazard ratio as well as individual hazard ratios are shown in Fig. (1a-c).

\section{RESULTS}

The hazard ratios corresponding to different definitions varied slightly among studies and even within a study, but the overall hazard ratios calculated based on the metaanalysis of all studies were, however, similar around 1.7 (Fig. 1a-c) for all definitions studied.

In the meta-analysis of 6 Finnish and Swedish cohorts of 4038 men and 3813 women of 25-74 years old, the risk size of different definitions as well as their individual components has been compared using paired homogeneity test [28]. During follow-up of 4 to 12 years, 113 incident ischemic stroke events in men and 47 in women were accumulated. The hazard ratio for each of the full definitions of the metabolic syndrome was presented in the Table 2, they were not statistically significantly different from each other [28]. The hazard ratios for ischemic stroke in men were 2.09 (1.39$3.14)$ and $1.86(1.17-2.98)$ for FPG of 6.1-6.9 mmol/l and for elevated blood pressure of $\geq 140 / 90 \mathrm{mmHg}$ or treated, and $3.21(1.61-6.39)$ and $2.61(1.24-5.50)$ in women, respectively. When a full definition of the metabolic syndrome was compared with its single components the study did not find that a full definition was superior to its single components with regard to the prediction of the ischemic stroke. None of the four definitions of the metabolic syndrome or its single components predicted hemorrhagic stroke except for the elevated blood pressure, hazard ratios of 2.78 (1.21-6.39) in men and 8.30 (2.11-32.63) in women for blood pressure of $140 / 90 \mathrm{mmHg}$ or treated [28]. The study concluded that metabolic syndrome as well as its individual components predicted the incidence ischemic stroke equally well and should be treated equally as well.

\section{CONCLUSIONS}

Regardless of the differences in definitions of the metabolic syndrome, the risk sizes for stroke are similar (hazard ratio of 1.7) among different definitions, which was lower than those reported for the incidence of type 2 diabetes (hazard ratios of 3.5 to 5.1) [16]. This is because the components included in these definitions are more or less similar, and the component that appears most frequently among all others is the elevated blood pressure. Elevated blood pressure is alone a strong risk factor for either ischemic or hemorrhagic stroke, and the risk size is similar to those of its full definitions [28]. A cluster of elevated blood pressure with others seems do not further increase the risk of stroke. It has been shown that type 2 diabetes clustering with hypertension was more strongly associated with the concurrence of cardiovascular events than other clusters of the metabolic syndrome among type 2 diabetic patients [30].

There are many different ways to diagnose a metabolic syndrome. This creates different traits of individuals identified as having the syndrome, some with high CVD risk but others low risk [30]. Because the inter-individual heterogeneity, the syndrome can not be considered as a single disease entity. Currently there is no a single treatment targeting at the syndrome rather than at each of its single components. From a clinical as well as a public health point of view, to increase the awareness of the clustering of certain metabolic disorders among doctors and public may help to identify people with multiple risk factors and lead to a poly pills treatment to prevent further progress to more serious clinical end points. The causes underlying the clustering and its pathophysiological changes require further researches. The relationship of metabolic syndrome with subtypes of stroke rather than ischemic stroke may need further clarification. 
Table 2. Hazard Ratio (95\% CI) of Stroke Incidence in Relation to the Presence of Metabolic Syndrome at Baseline in Studies of Population-Based

\begin{tabular}{|c|c|c|c|c|c|c|c|}
\hline Studies & $\begin{array}{c}\text { Age } \\
\text { (Year) }\end{array}$ & No. & $\begin{array}{l}\text { Follow-Up } \\
\quad \text { (Year) }\end{array}$ & $\begin{array}{l}\text { Stroke Type } \\
\text { Number }\end{array}$ & Definition & Hazard Ratio & Adjustment and Comment \\
\hline $\begin{array}{l}\text { McNeill (2005) } \\
\text { American white } \\
\quad \& \text { black }\end{array}$ & $45-64$ & $\begin{array}{c}\text { Men5208 } \\
\text { Women } 6881\end{array}$ & $\begin{array}{c}11 \\
\text { (mean) }\end{array}$ & $\begin{array}{c}\text { Ischemic } \\
\text { Men } 123 \\
\text { Women } 93\end{array}$ & $\begin{array}{l}\text { NCEP_2001 } \\
\text { NCEP_2004 }\end{array}$ & $\begin{array}{c}\text { Men } 1.42(0.96-2.11) \\
\text { Women } 1.96(1.28-3.00) \\
\text { Men } 1.52(1.05-2.18) \\
\text { Women } 1.90(1.25-2.89)\end{array}$ & $\begin{array}{l}\text { Age, race, study center, } \\
\text { LDL cholesterol, smoking. } \\
\text { In non-diabetics. }\end{array}$ \\
\hline $\begin{array}{l}\text { McNeill (2006) } \\
\text { American white } \\
\quad \text { \&black }\end{array}$ & $\geq 65$ & $\begin{array}{c}\text { Men } 1356 \\
\text { Women } 2229\end{array}$ & $\begin{array}{l}11(\mathrm{me}- \\
\text { dian) }\end{array}$ & $\begin{array}{l}\text { Ischemic and } \\
\text { hemorrhagic } \\
\text { Men } 146 \\
\text { Women } 255\end{array}$ & NCEP_2004 & $\begin{array}{c}\text { Men } 1.51(1.08-2.12) \\
\text { Women } 0.94(0.73-1.21)\end{array}$ & $\begin{array}{l}\text { Age and race. } \\
\text { In non-diabetics. }\end{array}$ \\
\hline $\begin{array}{c}\text { Kurl } 2006 \\
\text { Finnish men }\end{array}$ & $42-60$ & Men 1131 & 14 (mean) & Men 65 & $\begin{array}{c}\text { NCEP_2004 } \\
\text { WHO modified }\end{array}$ & $\begin{array}{c}\text { All } 2.39(1.17-4.89) \\
\text { Ischemic } 2.78(1.24-6.23) \\
\text { All } 2.08(1.12-3.87) \\
\text { Ischemic } 2.47(1.21-5.07)\end{array}$ & $\begin{array}{l}\text { Age, examination year, Socioeconomic } \\
\text { status, smoking, alcohol, family history of } \\
\text { heart disease, ischemic changes during } \\
\text { exercise test, LDL cholesterol, energy } \\
\text { intake for saturated fats, energy expenditure } \\
\text { of leisure time physical activity, blood } \\
\text { leukocyte count, and plasma fibrinogen } \\
\text { In non-diabetics. }\end{array}$ \\
\hline $\begin{array}{l}\text { Iso } 2007 \\
\text { Japanese }\end{array}$ & $40-69$ & $\begin{array}{c}\text { Men } 3595 \\
\text { Women } 5492\end{array}$ & 18 & $\begin{array}{c}\text { Ischemic } \\
\text { Men } 144 \\
\text { Women } 112\end{array}$ & $\begin{array}{l}\text { NCEP_2001, but } \\
\text { replacing waist with } \\
\text { BMI } \geq 25 \mathrm{~kg} / \mathrm{m}^{2}\end{array}$ & $\begin{array}{c}\text { Men } 2.0(1.3-3.1) \\
\text { Women } 1.5(1.0-2.3)\end{array}$ & $\begin{array}{l}\text { Age, sex, community, TC, smoking, alco- } \\
\text { hol, and menopause for women only. } \\
\text { Including diabetics. }\end{array}$ \\
\hline $\begin{array}{l}\text { Liu } 2007 \\
\text { Chinese }\end{array}$ & $35-64$ & $\begin{array}{c}\text { Men }+ \\
\text { women } 30378\end{array}$ & 10 & $\begin{array}{l}\text { Iscehmic\& } \\
\text { hemorrhagic } \\
\text { \# not available }\end{array}$ & $\begin{array}{l}\text { NCEP_2004, but } \\
\text { using waist } \geq 90 \\
(80) \mathrm{cm}\end{array}$ & $\begin{array}{c}\text { Ischemic } 2.41(1.98-2.94) \\
\text { hemorrhagic } 1.63(1.16-2.30)\end{array}$ & $\begin{array}{c}\text { Age, sex, smoking, CVD family history, } \\
\text { and TC } \\
\text { Including diabetics. }\end{array}$ \\
\hline $\begin{array}{c}\text { Ninomiya } 2007 \\
\text { Japanese }\end{array}$ & $\geq 40$ & $\begin{array}{c}\text { Men } 1050 \\
\text { Women } 1402\end{array}$ & 14 & $\begin{array}{c}\text { All stroke } \\
\text { Men } 94 \\
\text { Women } 115\end{array}$ & $\begin{array}{l}\text { NCEP_2001, but } \\
\text { waist } \geq 90(80) \mathrm{cm}\end{array}$ & $\begin{array}{c}\text { Men } 1.92(1.23-2.98) \\
\text { Women } 1.50(1.03-2.19)\end{array}$ & $\begin{array}{l}\text { Age, proteinuria, electrocardiogram abnor- } \\
\text { malities, serum total cholesterol, smoking } \\
\text { habits, alcohol intake, and regular exercise. } \\
\text { Including diabetics. }\end{array}$ \\
\hline $\begin{array}{c}\text { Wang } 2008 \\
\text { Finnish }\end{array}$ & $65-74$ & $\begin{array}{c}\text { Men+Women } \\
991\end{array}$ & 14 & $\begin{array}{c}\text { All stroke } \\
137\end{array}$ & $\begin{array}{l}\text { NCEP_2001 } \\
\text { NCEP_2004 } \\
\text { WHO } \\
\text { IDF }\end{array}$ & $\begin{array}{l}1.60(1.14-2.25) \\
1.49(1.06-2.10) \\
1.57(1.12-2.19) \\
1.77(1.24-2.54)\end{array}$ & $\begin{array}{c}\text { Age, Sex. } \\
\text { In non-diabetics. }\end{array}$ \\
\hline $\begin{array}{l}\text { Qiao } 2008 \\
\text { European }\end{array}$ & $25-74$ & $\begin{array}{c}\text { Men } 4038 \\
\text { Women } 3813\end{array}$ & $4-21$ & $\begin{array}{c}\text { Ischemic \& } \\
\text { Hemorrhagic } \\
\text { Men } 167 \\
\text { Women } 63\end{array}$ & $\begin{array}{l}\text { Ischemic stroke } \\
\text { NCEP_2001 } \\
\text { NCEP_2004 } \\
\text { WHO_modified } \\
\text { IDF }\end{array}$ & $\begin{array}{l}\text { Men } 1.52(1.01-2.28) \\
\text { Women } 2.68(1.47-4.87) \\
\text { Men } 1.16(0.77-1.74) \\
\text { Women } 2.31(1.27-4.20) \\
\text { Men } 1.59(1.09-2.32) \\
\text { Women } 2.20(1.15-4.19) \\
\text { Men } 1.27(0.87-1.86) \\
\text { Women } 1.91(1.05-3.49)\end{array}$ & $\begin{array}{l}\text { Age as time scale, adjusting for cohort, } \\
\text { smoking, and total cholesterol } \\
\text { In individuals without a prior history of } \\
\text { diabetes } \\
\text { No relationship was found for hemorrhagic } \\
\text { stroke. }\end{array}$ \\
\hline
\end{tabular}

\section{ACKNOWLEDGEMENT}

We would like to thank the Academy of Finland for the financial support (project 118492).

\section{ABBREVIATIONS}

$\begin{aligned} & \text { WHO }= \text { World Health Organization } \\ & \text { EGIR }= \text { The European Group for Study of Insulin Resis- } \\ & \text { tance }\end{aligned}$
NCEP $=$ The National Cholesterol Education Program Adult Treatment Expert Panel

IDF $=$ The International Diabetes Federation

$\mathrm{AACE}=$ The American Association of Clinical Endocrinologists

BMI $=$ Body mass index

WHR = Waist to hip ratio

CVD $=$ Cardiovascular disease

FPG $=$ Fasting plasma glucose 
(a)

1. McNeill 2005, men aged 45-64 years, Ischemic

2. McNeill 2005, women aged 45-64 years, Ischemic

3. Iso 2007, men aged 40-69 years, Ischemic

4. Iso 2007, women aged 40-69 years, Ischemic

5. Ninomiya 2007 , men, $\geq 40$ years old, all stroke

6. Ninomiya 2007, women, $\geq 40$ years old, all stroke

7. Wang 2008, men\&women aged 65-74 years, all stroke

8. Qiao 2008, men aged 25-74 years, Ischemic

9. Qiao 2008, women aged 25-74 years, Ischemic

Overall (meta-analysis)

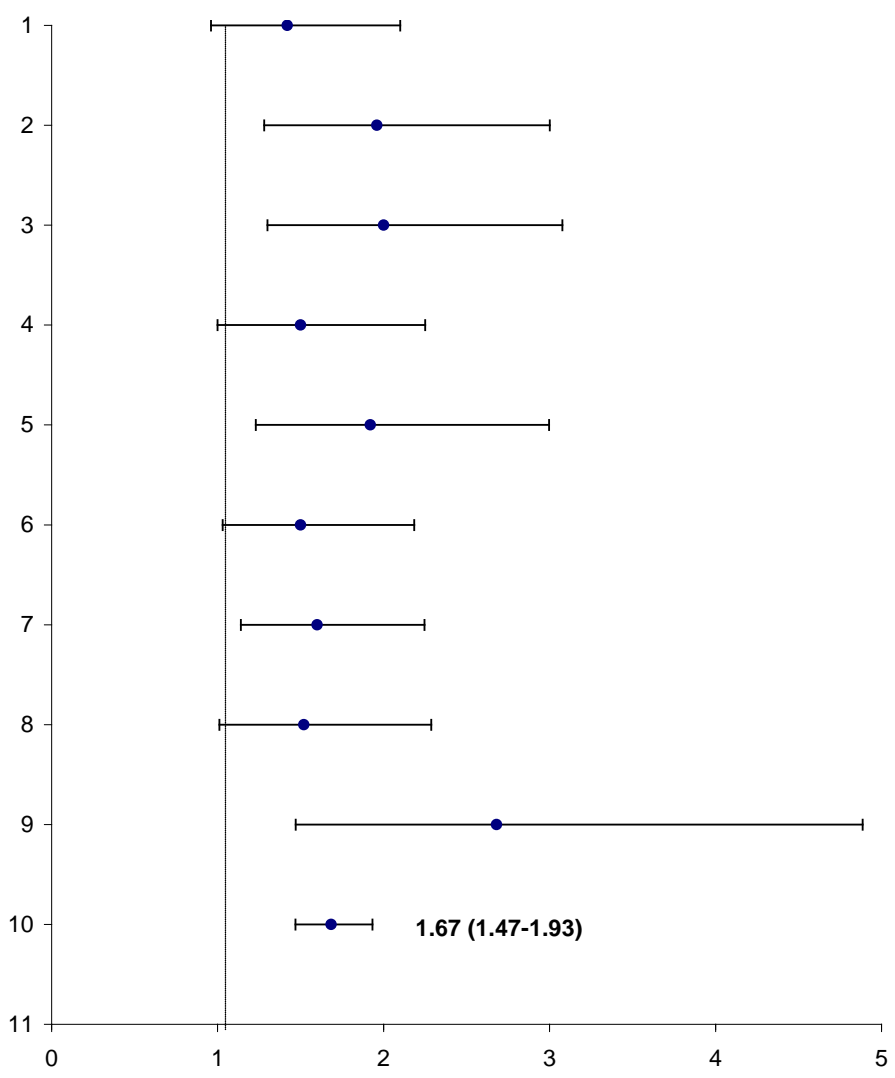

Relative risk (95\%CI) for stroke incidence, using NCEP 2001 definition

(b)

1. McNeill 2005, men aged 45-64 years, Ischemic

2. McNeill 2005, women aged 45-64 years, Ischemic

3. McNeill 2006, men, $\geq 65$ years old, ischemic\&hemorrhagic 3

4. McNeill 2006, women, $\geq 65$ years old,

5. Kurl 2006, men aged 42-60 years, all stroke

6. Kurl 2006, men aged 42-60 years, ischemic

7. Liu 2007, men and women aged 35-64 years, ischemic

8. Liu 2007, men and women aged 35-64 years, hemorrhagic

9. Qiao 2008, men aged 25-74 years, ischemic

10. Qiao 2008, women aged 25-74 years, ischemic

Overall (meta-analysis)

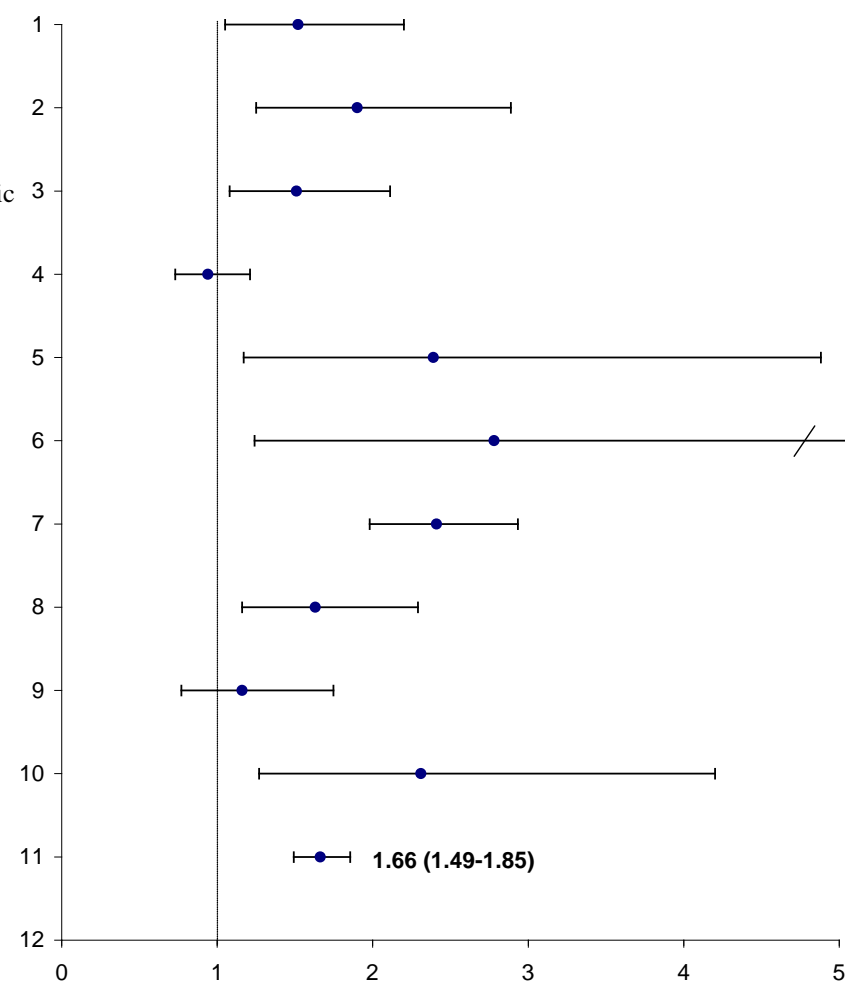

Relative risk (95\%CI) for stroke incidence, using NCEP 2004 definition 
(c)

1. Kurl 2006, men aged 42-60 years, all stroke

2. Kurl 2006, men aged 42-60 years,

3. Wang 2008, men and women aged $65-74$ years, all

4. Wang 2008 , men and women aged $65-74$ years *, all

5. Qiao 2008, men aged 25-74 years, Ischemic

6. Qiao 2008, women aged 25-74 years, Ischemic

7. Qiao 2008, men aged 25-74 years*, Ischemic

8. Qiao 2008, women aged 25-74 years*, Ischemic

Overall (meta-analysis)
(Fig. 1) contd....

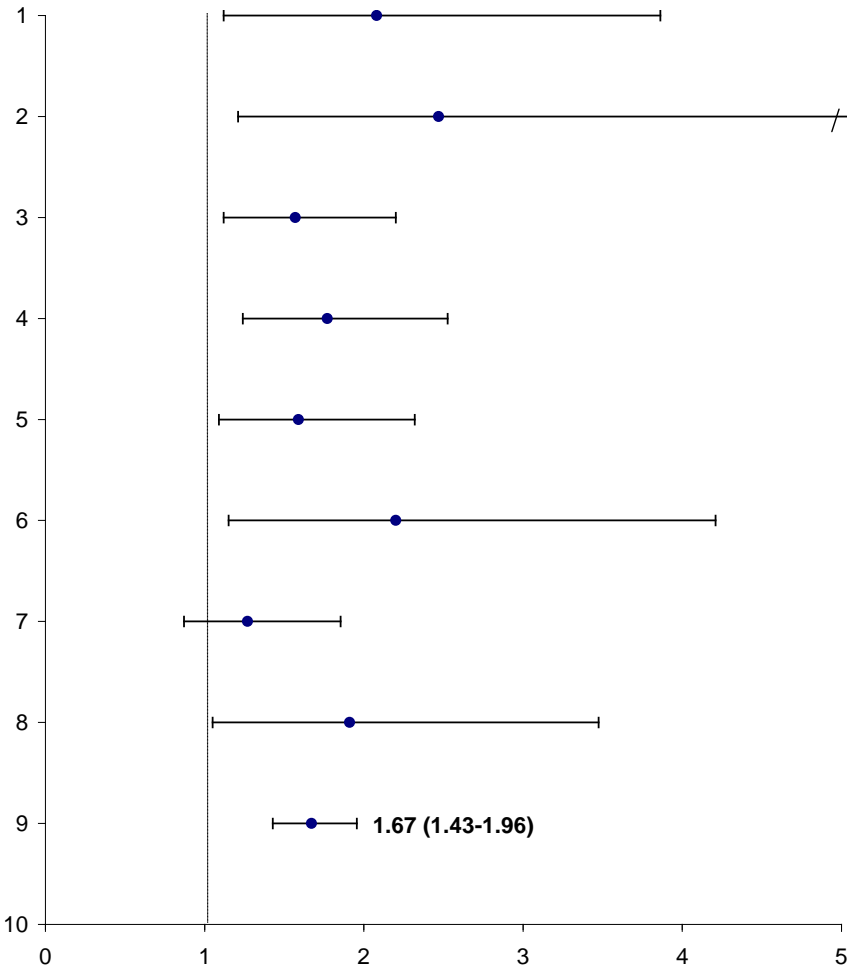

Relative risk (95\%CI) for stroke incidence, using WHO or IDF $\left(^{*}\right)$ definition

Fig. (1). Meta-analysis of the effect of metabolic syndrome on stroke incidence using the NCEP_2001 (a) NCEP_2004 (b) and the WHO/IDF definition (c).

\section{REFERENCES}

[1] Alberti KG, Zimmet PZ. Definition, diagnosis and classification of diabetes mellitus and its complications. Part 1: diagnosis and classification of diabetes mellitus provisional report of a WHO consultation. Diabet Med 1998; 15: 539-53.

[2] WHO Consultation. Definition, diagnosis and classification of diabetes mellitus and its complications. Part 1: diagnosis and classification of diabetes mellitus. Geneva: World Health Organisation 1999; Report No. 99.2.

[3] Balkau B, Charles MA. Comment on the provisional report from the WHO consultation. European Group for the Study of Insulin Resistance (EGIR). Diabet Med 1999; 16: 442-3.

[4] Adult Treatment Panel III. Third report of the National Cholesterol Education Program (NCEP) expert panel on detection, evaluation, and treatment of high blood cholesterol in adults (Adult Treatment Panel III) final report. Circulation 2002; 106: 3143-421.

[5] Expert panel on detection E, and treatment of high blood cholesterol in adults, executive summary of the third report of the National Cholesterol Education Program (NCEP) expert panel on detection, evaluation, and treatment of high blood cholesterol in adults (Adult Treatment Panel III). JAMA 2001; 285: 2486-97.

[6] Grundy SM, Brewer HB, Jr., Cleeman JI, Smith SC, Jr., Lenfant C. Definition of metabolic syndrome: report of the National Heart, Lung, and Blood Institute/American Heart Association conference on scientific issues related to definition. Arterioscler Thromb Vasc Biol 2004; 24: e13-8.

[7] Bloomgarden ZT. American Association of Clinical Endocrinologists (AACE) consensus conference on the insulin resistance syndrome: 25-26 August 2002, Washington, DC. Diabetes Care 2003; 26: 1297-303.

[8] American College of Endocrinology Task Force on the Insulin Resistance Syndrome. American College of Endocrinology Position Statement on the Insulin Resistance Syndrome. Endocr Pract 2003; 9: 237-52.

[9] Alberti KG, Zimmet P, Shaw J. The metabolic syndrome: a new worldwide definition. Lancet 2005; 366: 1059-62.
[10] Alberti KGMM, Zimmet P, Shaw J. Metabolic syndrome : a new world-wide definition. A Consensus Statement from the International Diabetes Federation. Diabet Med 2006; 23: 469-80.

[11] The DECODE Study Group. Comparison of three different definitions for the metabolic syndrome in non-diabetic Europeans. $\mathrm{Br} \mathrm{J}$ Diabetes Vasc Dis 2005; 5: 161-8.

[12] Qiao Q, Gao WG, Zhang L, Nyamdorj R, Tuomilehto J. Metabolic syndrome and cardiovascular disease. Ann Clin Biochem 2007; 44: 232-63.

[13] Ford ES. Risks for all-cause mortality, cardiovascular disease, and diabetes associated with the metabolic syndrome: a summary of the evidence. Diabetes Care 2005; 28: 1769-78.

[14] Galassi A, Reynolds K, He J. Metabolic syndrome and risk of cardiovascular disease: a meta-analysis. Am J Med 2006; 119: 8129.

[15] Gami AS, Witt BJ, Howard DE, et al. Metabolic syndrome and risk of incident cardiovascular events and death: a systematic review and meta-analysis of longitudinal studies. J Am Coll Cardiol 2007; 49: 403-14.

[16] Ford ES, Li C, Sattar N. Metabolic syndrome and incident diabetes: current state of the evidence. Diabetes Care 2008; 31: 1898-904.

[17] Sattar N, McConnachie A, Shaper AG, et al. Can metabolic syndrome usefully predict cardiovascular disease and diabetes? Outcome data from two prospective studies. Lancet 2008; 371: 192735 .

[18] The DECODE Study Group. Comparison of different definitions of the metabolic syndrome in relation to cardiovascular mortality in European men and women. Diabetologia 2006; 49: 2837-46.

[19] Lawlor DA, Smith GD, Ebrahim S. Does the new International Diabetes Federation definition of the metabolic syndrome predict CHD any more strongly than older definitions? Findings from the British Women's Heart and Health Study. Diabetologia 2006; 49: 41-8.

[20] Nilsson PM, Engstrom G, Hedblad B. The metabolic syndrome and incidence of cardiovascular disease in non-diabetic subjects--a population-based study comparing three different definitions. Diabet Med 2007; $24:$ 464-72. 
[21] McNeill AM, Katz R, Girman CJ, et al. Metabolic syndrome and cardiovascular disease in older people: the cardiovascular health study. J Am Geriatr Soc 2006; 54: 1317-24.

[22] McNeill AM, Rosamond WD, Girman CJ, et al. The metabolic syndrome and 11-year risk of incident cardiovascular disease in the atherosclerosis risk in communities study. Diabetes Care 2005; 28 : 385-90.

[23] Kurl S, Laukkanen JA, Niskanen L, et al. Metabolic syndrome and the risk of stroke in middle-aged men. Stroke 2006; 37: 806-11.

[24] Wang J, Ruotsalainen S, Moilanen L, Lepisto P, Laakso M, Kuusisto J. The metabolic syndrome predicts incident stroke: a 14year follow-up study in elderly people in Finland. Stroke 2008; 39 : 1078-83.

[25] Iso H, Sato S, Kitamura A, et al. Metabolic syndrome and the risk of ischemic heart disease and stroke among Japanese men and women. Stroke 2007; 38: 1744-51.
[26] Ninomiya T, Kubo M, Doi Y, et al. Impact of metabolic syndrome on the development of cardiovascular disease in a general Japanese population: the Hisayama study. Stroke 2007; 38: 2063-9.

[27] Liu J, Grundy SM, Wang W, et al. Ten-year risk of cardiovascular incidence related to diabetes, prediabetes, and the metabolic syndrome. Am Heart J 2007; 153: 552-8.

[28] Qiao Q, Laatikainen T, Zethelius B, et al. Comparison of definitions of metabolic syndrome in relation to the risk of developing stroke and coronary heart disease in Finnish and Swedish Cohorts. Stroke 2009; 40(2): 337-43.

[29] Fleiss JL. The statistical basis of meta-analysis. Stat Methods Med Res 1993; 2: 121-45

[30] Hanefeld M, Koehler C, Gallo S, Benke I, Ott P. Impact of the individual components of the metabolic syndrome and their different combinations on the prevalence of atherosclerotic vascular disease in type 2 diabetes: the Diabetes in Germany (DIG) study. Cardiovasc Diabetol 2007; 6: 13.

(C) Qiao et al.; Licensee Bentham Open.

This is an open access article licensed under the terms of the Creative Commons Attribution Non-Commercial License (http: //creativecommons.org/licenses/ by-nc/3.0/) which permits unrestricted, non-commercial use, distribution and reproduction in any medium, provided the work is properly cited. 